Autora: Érica da Silva Reimer

Orientadores: Emílio Velloso Barroso e Antonio José Teixeira Guerra

Título: Inventário dos Movimentos de Massa e Análise da Suscetibilidade aos Escorregamentos Rasos em Solo no Distrito de Cascatinha, Petrópolis, RJ

№ de páginas: 125

\title{
Resumo:
}

A Cidade Imperial de Petrópolis tem crescido continuamente desde sua fundação e as maiores taxas foram registradas entre os anos de 1950 a 1980. Sua beleza natural e suas condições climáticas agradáveis têm atraído pessoas de cidades vizinhas e de outros estados brasileiros. Infelizmente da mesma forma como observado para muitas cidades em todo o mundo, o crescimento da população não é amparado por programas que sejam capazes 


\section{Programa de Pós-Graduação em Geologia}

Dissertações - Mestrado

de organizar o espaço urbano considerando os limites do meio físico. Isto é particularmente verdadeiro para a região de Cascatinha, uma área de expansão urbana. Como conseqüência uma série problemas relacionados a processos de movimentos de massa freqüentemente ocorrem, sendo que os escorregamentos são os mais importantes porque causam prejuízos econômicos e mortes. Depois de um extenso inventário dos eventos históricos ocorridos na área de estudo, foi observado que os escorregamentos rasos de solos representam o tipo mais freqüente de problema de instabilidade. Devido a limitações no número e na distribuição não uniforme dos registros de escorregamentos, uma parte da área total do Distrito de Cascatinha foi escolhida como piloto para a análise da suscetibilidade a escorregamentos rasos de solo. Atributos como a geologia, pedologia, tipo de solo, gradiente, forma das vertentes e uso do solo foram descritos para cada registro de escorregamento. A combinação desses atributos gerou diversas classes, cujas freqüências acumuladas foram consideradas para definir áreas de diferentes suscetibilidades a escorregamentos rasos de solos. Para mapear essas áreas uma rotina Booleana foi implementada em ambiente SIG (SPRING). Os resultados obtidos parecem consistentes e representam um passo inicial para uma metodologia de análise de risco. Podemos concluir que o estudo isolado dos condicionantes não é indicado, pois não permite uma visualização adequada do cenário induzindo a erros na interpretação das áreas suscetíveis. 